\title{
A Comparative Study of E-learning Platform in Reading and Translating Course for Engineering Students
}

\author{
http://dx.doi.org/10.3991/ijet.v11i04.5551 \\ Xue Shi \\ Luoyang Institute of Science and Technology, Luoyang, China
}

\begin{abstract}
Web-based learning environments are being more widely used in higher education to support face to face teaching activities. Universities in Europe, the United States, and other developed countries extensively use e-learning platforms; however, this is still in the trial stage in Chinese universities and educational institutions. Moodle has been considered as an interactive e-learning tool to motivate students and involve them in resolving both individual and collaborative tasks. In order to improve class attendance and homework assignments submission, an e-course was developed via Moodle and proved to be a positive teaching/learning experience. Following this study, a series of conclusions can be drawn concerning its benefits in terms of stimulating students' interest in homework tasks and increasing their frequency of interaction with teachers and among colleagues.
\end{abstract}

Index Terms-e-learning, e-course, Moodle, higher education

\section{INTRODUCTION}

Technology plays an important role in many aspects of daily life, and its importance for education is by no means different. Over the last decade, the idea of applying Moodle (Modular Object-Oriented Dynamic Learning Environment) in higher education has been increasingly adopted by universities and other academic institutions.

Moodle is a learning platform originally designed by Martin Dougiamas (first version of Moodle was released on 20 August 2002). Moodle, as a robust open-source elearning platform, and was used and developed in the years following its release by a global collaborative effort of the international community. Moodle is designed and continually improves to provide educators, administrators and learners with a single robust, secure and integrated system to create personalized learning environments [1].

The above mentioned e-learning platform was installed within Luoyang Institute of Science and Technology in recent years and it definitely contributes to making the teaching and learning process between students and professors more efficient and effective. However, its use has not become compulsory so far and it is used as a learning resource, as a means of teaching-learning as a supplement conventional lectures. Since 2013, the web-based platform Moodle has been used as a means of e-learning in writing courses for linguistic students. Because of its flexibility and simplicity for navigation and creation of course material, a growing number of students have shown interest in enrolling. Therefore, we consider Moodle as an e-learning platform to support face to face teaching.

In response to increasing demand among non-linguistic faculties for foreign language learning, a novel e-course in reading and translation for engineering students was developed. The aim of this study was to determine whether this new teaching method is suitable for third-year undergraduate students and to compare attitudes and results of students who followed electronic study versus conventional classroom study.

\section{LITERATURE REVIEW}

There are many reasons for the growth of the e-learning industry, both from the universities and students' perspectives. Generally speaking, the demand for distance learning is increasing. The flexibility and availability of elearning can ensure further professional development beyond the classroom. K. Werbach [2] pointed out that with the limited capacity of classrooms and limited budgets for building new facilities, e-learning was an ideal alternative to traditional teaching methods. D. Benta explained, from the perspective of students [1], how e-learning helped them access the course materials as well as motivated them to collaborate with their colleagues in doing homework.

Despite the above advantages, most Chinese universities continue to employ only traditional teaching methods with no other additional support. S.C. Wang [3] considered the online courses as simply a copy of the traditional classroom teaching, as the teaching content was basically the same. L.Y. Zhu [4] proposed that teachers had less supervision of the learning process. J. Wei [5] and J. Guo [6] hold that Chinese teachers were more likely to have face-to-face communication with students, and students might better maintain self discipline in classrooms compared with online learning.

\section{METhODOLOGY}

\section{A. Analysis Of The E-Learning Platform}

Utilizing the benefits from using e-learning platforms to support traditional classroom teaching is a growing tendency in educational practices. One type of e-learning platform, Moodle, enables the content management (courses, homework), ensures synchronized collaboration (by chat or videoconference) as well as non-synchronized collaboration (forum, message, blog.) and, it can be used in managing the students that applied for the course [7-8]. 
PAPER

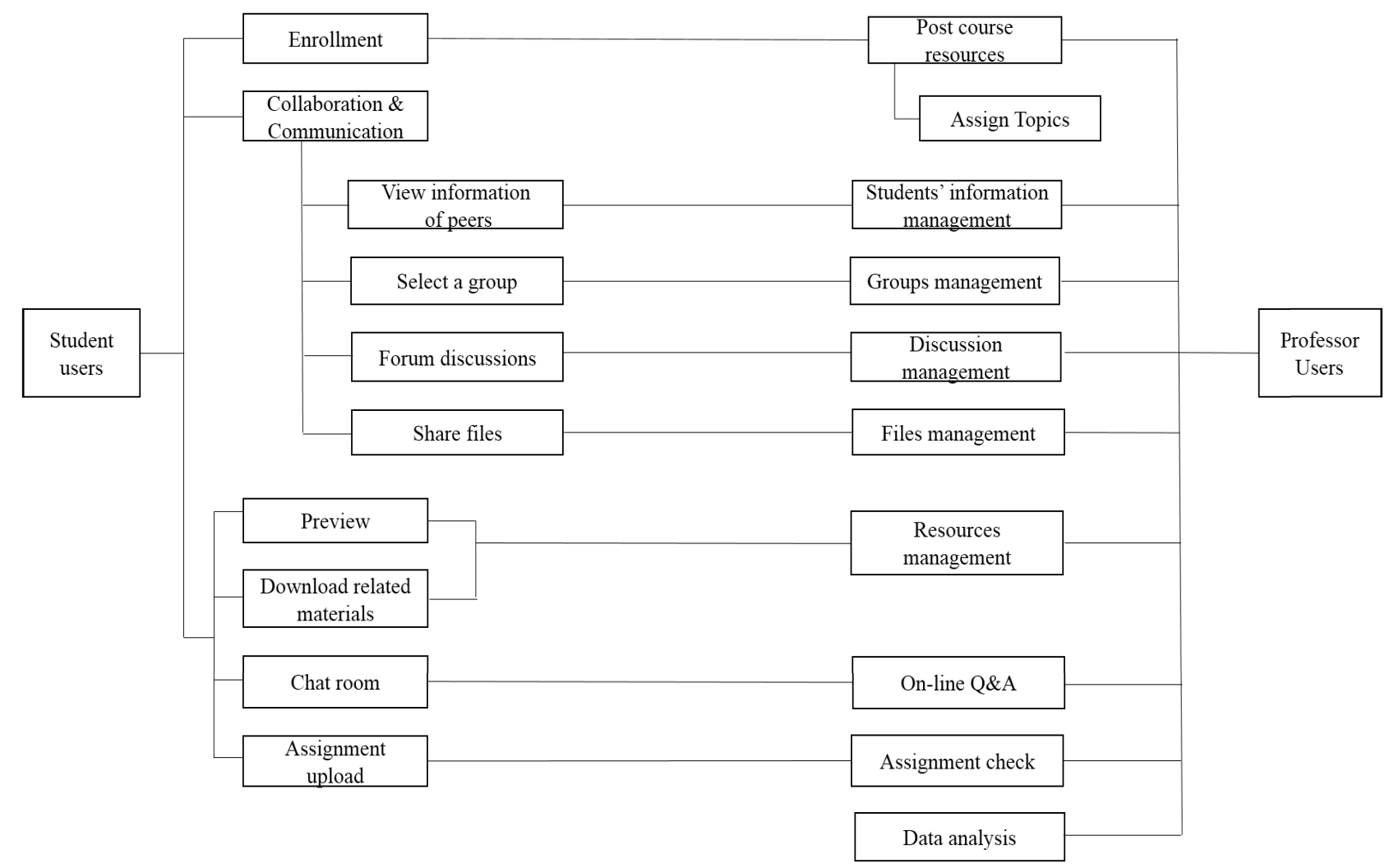

Figure 1. Multifunctional Interactive Environment via Moodle

By means of this platform a multifunctional interactive environment between professors and students is provided, as shown in Figure 1. Within this platform students learn by direct, collaborative participation, where both students and their professors can have synchronized or nonsynchronized access to the platform [9-10]. A series of communication facilities, such as forums, chat rooms and message systems are provided by this e-learning platform. By means of forum discussion, students can communicate with their peers or professors in a non-synchronized manner at any time, as long as there is an internet connection. The forum discussions can be related to general topics of interest or can be focused on a specific topic, where either student users or professor users can initiate a discussion. Unlike the forum, the chat room system provides a synchronized communication opportunity for all users on the course platform at a given time, which leads to real-time discussion [11-12]. Through the message system, users can conduct private communication among themselves, and students can view their peers' information or share files with them.

This e-learning platform enables good communication and socialization by means of chat or forum, both between students and professors. Individual communication with the professors can be achieved or topics can be discussed by all users that access the platform [13-14].

\section{B. General Layout Of The Course}

The course of Reading and Translating at the Faculty of Material Science, Luoyang Institute of Science and Technology is compulsory for engineering students in the fifth semester of undergraduate studies. Students, 179 in total, who passed Comprehensive English, held in the first four semesters, entered this course. The course lasts for 16 weeks (from September to December, 2015) and is com- posed of lectures (10 weeks, held once a week), oral presentation ( 5 weeks, after lectures) and a final examination (in the last week). According to the bylaws of the Faculty of Material Science, a lecture on the same topic was held from Monday to Wednesday. Students who chose classroom seminars were divided into 3 subgroups to follow the course on a certain day. E-seminar students would follow the lectures on-line on the same topics as scheduled. Lectures focused on explaining engineering related terms, reading comprehension and translation skills. A team of five or six students was required to give an oral presentation, lasting up to $20 \mathrm{~min}$, using Power Point, in front of other students (for classroom students) or through videoconference (for e-learning platform students) on a topic delegated by the teaching assistant in charge of that team. A 25 minute period of questions, comments and discussion followed the presentation. In the last week, all students attended the final exam which was a paper test of 100 points for passage reading and translation.

All topics for lectures, as shown in Table I, were printed and distributed to students two weeks in advance of the start of the course, during which time these 179 students could consider whether or not to take participate in the elearning platform. Those who applied for the platform learning format were exempt from attending classes when corresponding lectures were scheduled. Students had to create their own username and password in order to access the e-learning platform. The results of students' choices and the basic information is shown in Table II, which shows no apparent difference in the two groups, except that males more tend to prefer e-learning platform $(54.5 \%$ of males (72/132) prefered to take e-seminars, while only $40.4 \%$ of females (19/47) did so). 
PAPER

A COMPARATIVE Study of E-LEARning PlatForm in REAding AND TRANSLATING CoURSE FOR ENGINEERING...

TABLE I.

TEACHING CONTENTS IN READING AND TRANSLATING FOR THIRD-YEAR ENGINEERING STUDENTS

\begin{tabular}{|l|l|}
\hline & \\
\hline Week 1 & Introduction to Material Science and Engineering \\
\hline Week 2 & Materials: Ferrous Alloys and Non-ferrous Alloys \\
\hline Week 3 & Materials: Advanced Structural Ceramics and Functional Ceramics \\
\hline Week 4 & Introduction to Welding Process \\
\hline Week 5 & Welding Metallurgy \\
\hline Week 6 & Metal Flow in Die Casting \\
\hline Week 7 & Optimization of Properties in Aluminum Casting \\
\hline Week 8 & Bulk-metal Forming and Sheet-metal Forming \\
\hline Week 9 & Heat Treatment of Steel \\
\hline Week 10 & Principle of Heat Treatment of Steel \\
\hline Week 11 & Presentation topic: Classification of Materials \\
\hline Week 12 & Presentation topic: Introduction of Polymer, Semiconductor or Composites \\
\hline Week 13 & Presentation topic: Some new Developments in Welding \\
\hline Week 14 & Presentation topic: Precision Casting Process \\
\hline Week 15 & Presentation topic: Fundamental of Metal Forming \\
\hline
\end{tabular}

TABLE II.

GENERAL INFORMATION FOR STUDENTS OF TRADITIONAL CLASSROOMS VERSUS E-LEARNING PLATFORM

\begin{tabular}{|l|l|l|l|l|}
\hline & \multicolumn{1}{|c|}{ Number } & \multicolumn{1}{|c|}{ Males } & \multicolumn{1}{c|}{ Females } & \multicolumn{1}{|c|}{ GPA>80 } \\
\hline Traditional classrooms & 88 & 60 & 28 & $23.86 \%(21)$ \\
\hline E-learning platform & 91 & 72 & 19 & $25.27 \%(23)$ \\
\hline Total & 179 & 132 & 47 & - \\
\hline
\end{tabular}

\section{RESUlts AND Discussion}

\section{Pre-Course Survey}

To further evaluate the motives for enrollment in each situation, a short questionnaire was administered [15], related to several motives for enrollment and their initial expectations. Students in both situations were required to answer this survey before they accessed the first lecture topic. Each answer was rated on a Likert scale from 1 to 5,1 denoting "strongly disagree" and 5 denoting "strongly agree" with a given statement. Scores of the pre-course survey for each situation are presented in from Table III to Table VI. Students considered the reason "To enjoy the flexibility of learning" as the strongest motive to participate in e-learning platform.

The results of the pre-course survey are very optimistic. Students had high expectations of e-learning platform study which could be concluded from the result that no one chose "strongly disagree" to the statements. Students hoped to reap the benefits provided by the e-learning platform including access to an abundant amount of authentic materials, the hypertext structure, multimedia capabilities and online communication. Furthermore the easy accessibility and non-restricted time restraints of the net made it more flexible and attractive.

The preference of traditional classroom students suggests students' concerns about the e-learning platform include a lack of opportunities for in-depth and face-toface interaction between and among teachers and students, uncertain online learning goals without teachers' guidance and students' deficiency of online learning skills. Moreover, they were accustomed to the teacher-led classroom mode and were not confident in self-directed learning.
These findings prove that it is not a proper time for the e-learning platform to completely replace traditional classroom teaching since not all students are ready for that. At present, it is better to set a transitional period during which Moodle serves as a supporting teaching tool for classroom activities.

\section{Course Participation}

The class attendance subject is a very sensible one. The current situation is that the higher the students' grade, the lower the course participation. According to the faculty bylaws, attendance is calculated positively determined by grade. When Moodle was used, higher course participation was observed. From the total number of enrolled students, only $4 \%$ were absent, the remaining $96 \%$ attended the online courses (Figure 2-a). In the case where the traditional classroom teaching was employed, only $82 \%$ attended classes while $18 \%$ were absent (Figure 2b).

This was as expected. In the traditional way, students had to register with the faculty secretary and attend courses using printed resources. When using the elearning platform, students could log in via computers or mobile devices and download electronic resources.

Comparing the two situations, some remarks can be made. When the e-learning platform was used, it was more convenient for students to participate, as they found it very intuitive and easy to use. They were stimulated not only to think independently but also to participate in cooperation and discussion. There are many ways to encourage course participation and using e-learning platform is an effective one. 
PAPER

A Comparative Study of E-LEARning Platform in REAding ANd TRANSLAting Course For ENGineERING...

TABLE III.

REASONS FOR ENTERING THE COURSE FROM TRADITIONAL CLASSROOM STUDENTS

\begin{tabular}{|l|c|c|c|c|c|}
\hline & $\mathbf{1}$ & $\mathbf{2}$ & $\mathbf{3}$ & $\mathbf{4}$ & $\mathbf{5}$ \\
\hline 1. To have more face-to-face community & 0 & $5 \%$ & $6 \%$ & $11 \%$ & $78 \%$ \\
\hline 2. To follow teachers' instructions & 0 & 0 & $7 \%$ & $36 \%$ & $57 \%$ \\
\hline 3. To get immediate feedback & $1 \%$ & $8 \%$ & $17 \%$ & $32 \%$ & $42 \%$ \\
\hline 4. To maintain the status quo & $8 \%$ & $12 \%$ & $31 \%$ & $26 \%$ & $23 \%$ \\
\hline 5. To better self discipline while learning & $8 \%$ & $18 \%$ & $34 \%$ & $23 \%$ & $17 \%$ \\
\hline
\end{tabular}

TABLE IV

EXPECTATIONS FROM THE COURSE FROM TRADITIONAL CLASSROOM STUDENTS

\begin{tabular}{|l|c|c|c|c|c|}
\hline & $\mathbf{1}$ & $\mathbf{2}$ & $\mathbf{3}$ & $\mathbf{4}$ & $\mathbf{5}$ \\
\hline 1. To better learn the course material & 0 & 0 & $32 \%$ & $32 \%$ & $36 \%$ \\
\hline 2. To better bond with professors & 0 & $2 \%$ & $33 \%$ & $31 \%$ & $34 \%$ \\
\hline 3. To cultivate relationships with colleagues & 0 & 0 & $19 \%$ & $25 \%$ & $56 \%$ \\
\hline
\end{tabular}

TABLE V.

REASONS FOR ENTERING THE COURSE FROM E-LEARNING PLATFORM STUDENTS

\begin{tabular}{|l|c|c|c|c|c|}
\hline & $\mathbf{1}$ & $\mathbf{2}$ & $\mathbf{3}$ & $\mathbf{4}$ & $\mathbf{5}$ \\
\hline 1. To better learn the course material & 0 & $11 \%$ & $24 \%$ & $34 \%$ & $31 \%$ \\
\hline 2. To avoid physically coming to the class & 0 & 0 & $3 \%$ & $20 \%$ & $77 \%$ \\
\hline 3. To enjoy the flexibility of learning & 0 & 0 & $7 \%$ & $26 \%$ & $67 \%$ \\
\hline 4. To try a new mode of learning & 0 & $4 \%$ & $16 \%$ & $40 \%$ & $40 \%$ \\
\hline 5. To finish the homework faster & 0 & $15 \%$ & $42 \%$ & $22 \%$ & $21 \%$ \\
\hline
\end{tabular}

TABLE VI.

EXPECTATIONS FROM THE COURSE FROM E-LEARNING PLATFORM STUDENTS

\begin{tabular}{|l|c|c|c|c|c|}
\hline & $\mathbf{1}$ & $\mathbf{2}$ & $\mathbf{3}$ & $\mathbf{4}$ & $\mathbf{5}$ \\
\hline 1. To better learn the course material & 0 & 0 & $29 \%$ & $32 \%$ & $39 \%$ \\
\hline 2. To have fun while learning & 0 & 0 & $15 \%$ & $27 \%$ & $58 \%$ \\
\hline 3. To pick up something new & 0 & 0 & $30 \%$ & $31 \%$ & $40 \%$ \\
\hline
\end{tabular}

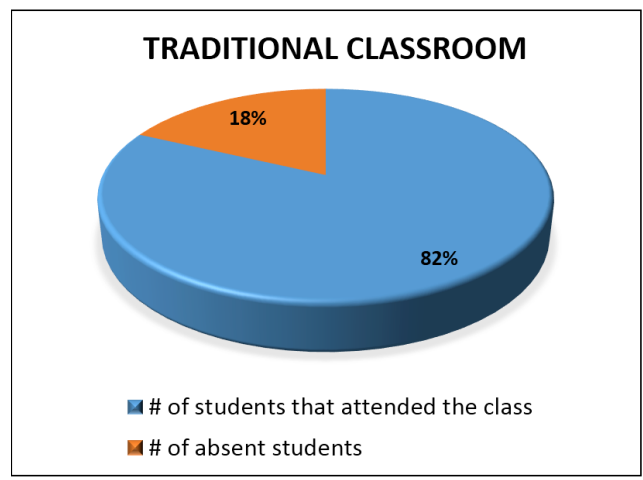

(a)

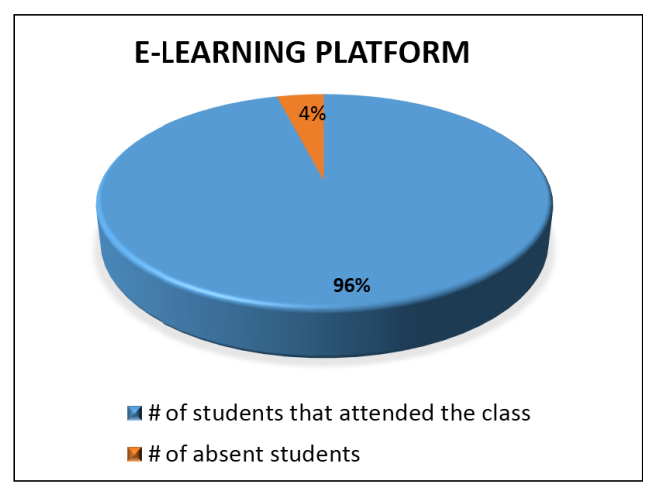

(b)

Figure 1. Course participation in traditional classroom versus e-learning platform

\section{E. Homework Submission}

The E-learning platform has proved useful in terms of homework tasks. A higher number of homework assignments were submitted using Moodle compared to the traditional way of submission by writing on a paper and handing it in (Figure 3). The difference is very significant; using the traditional way, only $78 \%$ of the total amounts of homework assigned were actually submitted. In contrast, when Moodle was used, $98 \%$ was recorded as submitted homework.
The reason behind this phenomenon is that students were not allowed to access the next lecture topic if they did not finish the homework before the deadline. In this way, students were stimulated to resolve homework on time. Further analysis of the server logs discovered that most of the performed and recorded tasks were homework-oriented tasks and as the deadline approached, there was a higher frequency and volume of platform usage and homework submissions. These facts prove that homework completion and submission were improved and students' interest in the course increased. 
PAPER

A COMPARATIVE Study of E-LEARning PlatForm in REAding AND TRANSLATing COURSE FOR ENGINEERING...

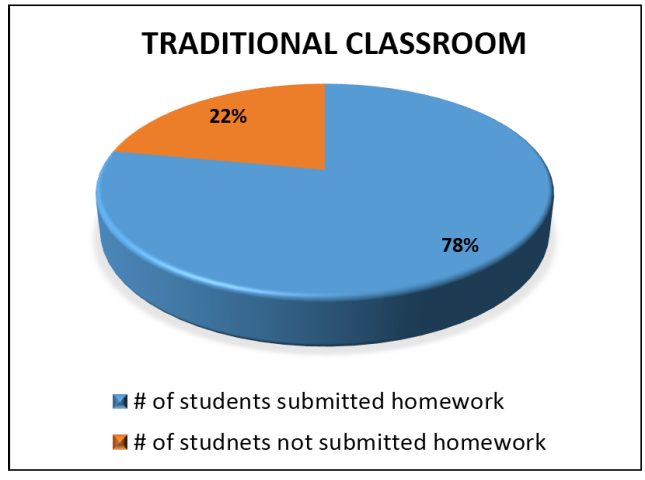

(a)

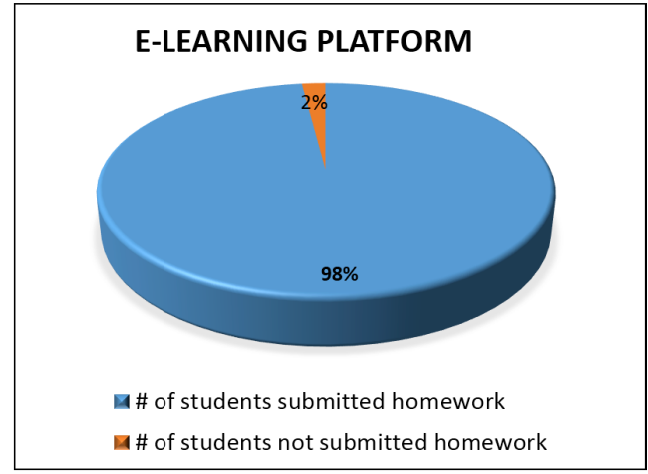

(b)

Figure 2. Homework submission in traditional classroom versus e-learning platform

\section{F. Course Communication}

Another benefit of the e-learning platform is that the virtual learning environment makes the students more active in class, especially for those who are shy in a traditional classroom setting. Some students are inhibited from asking questions in face-to-face classrooms, however, they readily ask questions or make comments online or in the Discussion Forum.

Table VII records the numbers of questions asked by students related to the course. A large gap can be observed between traditional class and e-learning class in the number of questions asked, which suggests that using the e-learning platform played a significant role in facilitating student participation and overall course communication between and among students and teachers. As other authors have pointed out, better communication will contribute to group development and fostering a sense of working as a team $[1,9,10]$. Through synchronized discussions or non-synchronized communications, students express points of confusion or doubt and they are more task oriented with few or no interpersonal conflicts as distractions.

\section{G. Post-Course Survey}

At the end of the 15th week, before the final exam, the post-course survey was conducted related to overall satisfaction, impression and future expectations for the course. Students in both situations had the same questions and possible answers to the six statements and were also rated on a Likert scale from 1 to 5 while the last question is open-ended. The positive attitudes to statements 4 and 5 highlight the difference.

As seen in the results given in Table VIII, students were more satisfied overall with the e-learning platform. At the same time, they have many expectations for the functions of the platform, such as:

- Automatic check for homework

- More on-line tests

- More friendly learning environment

- Quick feedback

Students of the traditional setting display a lower percentage of satisfaction. Their expectation for the course mainly includes:

- More interaction with teachers in classroom

- Clear learning object and instructions from teachers

- More active learning environment

- Variety of teaching aids

TABLE VII.

COMPARISON OF COURSE COMMUNICATION

\begin{tabular}{|l|c|c|}
\hline & Questions asked during 1-10 weeks (lecture) & Questions asked during 11-15 weeks(presentation) \\
\hline Traditional classroom & 35 & 97 \\
\hline E-learning platform & 106 & 368 \\
\hline
\end{tabular}

TABLE VIII.

COMPARISON OF POST-COURSE SURVEY

\begin{tabular}{|l|c|c|}
\hline \multicolumn{1}{|c|}{ Item } & \multicolumn{2}{c|}{ Percentage of students with positive attitude } \\
\cline { 2 - 3 } & Traditional classroom & E-learning platform \\
\hline 1. My reading and translating skills were improved & $62 / 88(70.4)$ & $66 / 91(72.5)$ \\
\hline 2. I had fun while learning & $45 / 88(51.1)$ & $80 / 91(87.9)$ \\
\hline 3. This mode of learning is much better than the other one & $37 / 88(42.0)$ & $70 / 91(76.9)$ \\
\hline 4. I would recommend this mode to other students & $41 / 88(46.6)$ & $91 / 91(100.0)$ \\
\hline 5. I'd like other courses to adopt this mode & $39 / 88(44.3)$ & $91 / 91(100.0)$ \\
\hline 6. I feel ready for the final examination & $49 / 88(54.5)$ & $52 / 91(57.1)$ \\
\hline
\end{tabular}




\section{CONCLUSIONS}

Although it cannot replace traditional education in a classroom setting, the effects of using an e-learning platform to support teaching can be concluded from three aspects:

(1) Moodle is a cost-effective learning environment which stimulates students' interest in the course and their commitment to finishing assignments. With more and more installment in Chinese universities, the Moodle platform will definitely have a significant and positive impact on the teaching-learning process.

(2) Based on this comparative study, the e-learning platform has been considered as a support for students in order to facilitate their learning. They are more involved in the course and more actively interact with professors and their colleagues through the on-line chat room or discussion forum. So far, it has proved to be a successful experience.

(3) In the future, more and more courses will be posted on this platform. However, according to the feedback from students, a number of functions need to be improved and both teacher and student users' demands should be taken into consideration. As a final conclusion, this elearning platform is highly recommended in supporting teaching activities, homework tasks and course communication.

\section{REFERENCES}

[1] D. Benta, G. Bologa, I. Dzitac, "E-learning Platforms in Higher Education. Case Study," Procedia Computer Science, 2014, vol. 27, no. 11, pp. 1170-1176. http://dx.doi.org/10.1016/j.procs.2014. $\underline{05.373}$

[2] K. Werbach, "Clicks and Mortar Meets Cap and Gown: Higher Education Goes Online," Realese 1.0, 2000, vol. 18. no. 8, pp. 122

[3] S.C. Wang, "Teachers' Role in Computer Assisted Language Learning," Asia-Pacific Education, 2014,vol. 21, no. 4, pp. 212213

[4] L.Y. Zhu, "The Current Situation and Thinking of Computer Assisted Language Teaching in Colleges and Universities in China," Journal of Qiqihar Junior Teachers' College,2015, vol. 12, no. 4, pp. 129-131
[5] J. Wei, "An Exploration and Practice of the Moodle-based ManMachine Interaction Translation Teaching," Journal of Yunan Agricultural University, 2015, vol.12, no. 9, pp. 108-113

[6] J. Guo, "Explore Application of College English Oral Teaching Model Based on Moodle," The Guide of Science \& Education, 2015, vol. 36, no. 2, pp.89-90.

[7] M. Virtual. Learning Environments: Using, Choosing and Developing Weller Your VLE, London: Rouledge, 2007, pp. 4-5.

[8] G. Carmen. "A Study about Using E-learning Platform (Moodle) in University Teaching Process", Procedia-Social and Behavioral Science, 2014, vol.215, no. 10, pp. 426-432

[9] D. Benta, G. Bologa, S.Dzitac, I. Dzitac, "University Level Learning and Teaching via E-learning Platforms ," Procedia Computer Science, 2015, vol. 77, no. 5, pp. 1366-1373. http://dx.doi.org/10.1016/j.procs.2015.07.123

[10] D. Benţa, Ş. I.Niţchi,, R. F Paewop. "Efficient Team Building for On-Time Projects," Journal of Information Systems \& Operations Management, 2011, vol. 5, no.6. pp. 31-43.

[11] P. Koehn. "A Process Study of Computer-aided Translation". Machine Translation, vol.23, no.4, pp. 241-263, November 2009. http://dx.doi.org/10.1007/s10590-010-9076-3

[12] D. Carless. "Implementing task-based learning with young learners.” English Language Teaching Journal, vol.56, no.4, pp.389396, 2002. http://dx.doi.org/10.1093/elt/56.4.389

[13] Q. Xiaoqing, Quantitative Data Analysis in the Study of Foreign Language Teaching. Wuhan: Huazhong University of Science and Technology Press, 2004.

[14] R. Bullough, S. Pinnegar. "Guidelines for quality in autobiographical forms of self-learning research," Educational Researcher, vol.30, no.3, pp. 13-21, 2001. http://dx.doi.org/10.3102/ 0013189X030003013

[15] S. Gadzhanov, A. Nafalski, Z. Nedic. "Computerised Measurement Laboratory for Engineering Students". World Transaction on Engineering and Technology Education. 2014, vol. 12 , no. 3 , pp. $380-385$

\section{AUTHOR}

Xue Shi is a lecturer in School of Foreign Languages, Luoyang Institute of Science and Technology, Luoyang, 471023, China. Her research interests include the applied linguistics, English language teaching, etc. (email: xuewonder@aliyun.com)

Submitted 06 February 2016. Published as resubmitted by the author 23 March 206. 